http://dx.doi.org/10.18778/8088-187-7.35

Andrzej Wrzyszcz

\title{
Placówka Zapasowa Organów Resortu Sprawiedliwości Generalnego Gubernatorstwa w Görlitz 1944-1945
}

\section{Wprowadzenie}

rtykuł niniejszy stanowi kontynuację badań nad problematyką $A$ organów resortu sprawiedliwości Generalnego Gubernatorstwa w latach 1939-1945. Pierwsze ustalenia w tej kwestii zawarłem w publikacji pt. Z badań nad ewakuacja organów resortu sprawiedliwości Generalnego Gubernatorstwa w latach 1944-1945 ogłoszonej drukiem w czasopiśmie "Studia z Dziejów Państwa i Prawa Polskiego"11. Wielce Szanowny Jubilat Pan Profesor Jacek Matuszewski należał do grona założycieli tego periodyku, a potem był wieloletnim członkiem jego Komitetu redakcyjnego. W księdze jubileuszowej, która stanowi wyraz uznania dla twórczości naukowej Pana Profesora pozwoliłem sobie powrócić do problematyki zapoczątkowanej pod Jego patronatem w "Studiach z Dziejów Państwa i Prawa Polskiego".

Pod pojęciem resort sprawiedliwości GG rozumiemy organy podporządkowane kierownikowi Wydziału Sprawiedliwości w Urzędzie Generalnego Gubernatora (Abteilung Justiz im Amt des Generalgouverneurs), od grudnia roku 1940 kierownikowi Głównego Wydziału Sprawiedliwości w Rządzie Generalnego Gubernatorstwa (Hauptabteilung Justiz in der Regierung des Generalgouvernements). W praktyce zmiana ta wprowadzona została z dniem 1 kwietnia 1941 r. $^{2}$ Nie znanym dotąd na ziemiach

1 „Studia z Dziejów Państwa i Prawa Polskiego” [Kraków] 2008, t. XI, s. 263-275.

${ }^{2}$ C. Madajczyk, Polityka III Rzeszy w okupowanej Polsce, t. I, Warszawa 1970, s. 117119; W. Witkowski, Historia administracji w Polsce 1764-1989, Warszawa 2007, s. 390-391; K. Grünberg, B. Otręba, Hans Frank na Wawelu, Włocławek 2001, s. 49; A. Wrzyszcz, Okupacyjne sadownictwo niemieckie w Generalnym Gubernatorstwie 1939-1945. Organizacja i funkcjonowanie, Lublin 2008, s. 81-82. Opublikowana w 2015 r. monografia Generalnego Gubernatorstwa: M. Winstone, Generalne Gubernatorstwo. Mroczne serce Europy Hitlera, Poznań 2015, zawiera w tej kwestii istotny moim zdaniem błąd. Autor na stronie 69 stwierdził, że Joseph Bühler już w marcu 1940 r. został sekretarzem stanu w „rządzie GG”. 
polskich rozwiązaniem było utworzenie lokalnych organów administracji resortu sprawiedliwości na szczeblu dystryktów. Były to wydziały sprawiedliwości (Abteilung Justiz) w urzędach szefów dystryktów ${ }^{3}$.

Pod nadzorem tych instytucji resortowych funkcjonowały: sądy niemieckie (Deutsche Gerichte), wyższe sądy niemieckie (Deutsche Obergerichte), sądy specjalne (Sondergerichte), niemiecka władza oskarżenia (Deutsche Anklagebehörde), od 1 sierpnia 1943 r. prokuratura (Staatsanwaltschaft) oraz niemiecka adwokatura i ściśle z nią powiązany notariat niemiecki (Deutsche Rechtsanwälte und Notare). To był pion sądownictwa niemieckiego.

Drugi pion podległy resortowi sprawiedliwości Generalnego Gubernatorstwa to sądownictwo polskie (sądy grodzkie, okręgowe i apelacyjne, funkcjonowanie Sądu Najwyższego zawieszono i w okresie okupacji nigdy go nie przywrócono). W dniu 1 sierpnia 1941 r. przyłączono do GG dystrykt Galicja. Od tego momentu w niemieckich publikatorach urzędowych zamiast nazwy sądownictwo polskie zaczęto używać miana: sądownictwo nieniemieckie. W dystrykcie Galicja funkcjonował Sąd Apelacyjny we Lwowie, sądy okręgowe i sądy grodzkie. Okupanci niemieccy starali się zapewnić $\mathrm{w}$ tych sądach obsadę składającą się w większości z sędziów ukraińskich. Resortowi sprawiedliwości Generalnego Gubernatorstwa podlegały też polska adwokatura i notariat ${ }^{4}$.

Warto podkreślić, że na terenie GG funkcjonowały także inne organy niemieckie, które miały w swej nazwie rzeczownik sąd (niemieckie sądy wojskowe, wojskowe sądy doraźne, policyjne sądy doraźne, sądy SS i policji). Pozostawały one poza jurysdykcją resortu sprawiedliwości Generalnego Gubernatorstwa i zostaną w tym opracowaniu pominięte. To samo odnosi się oczywiście do sądownictwa Polskiego Państwa Podziemnego, które na terenie GG w sposób kategorycznie przeciwstawny realizowało zadania całkowicie odmienne niż resort sprawiedliwości Generalnego Gubernatorstwa.

Pierwsze działania ewakuacyjne organów podległych resortowi sprawiedliwości GG obserwujemy na terenie dystryktu Galicja od początku stycznia 1944 r. (przenosiny prowadzono do innych rejonów Generalnego Gubernatorstwa). Po kilku miesiącach proces ten został zahamowany, a w maju i czerwcu 1944 r. planowano nawet reaktywację funkcjonowania niektórych organów należących do resortu sprawiedliwości GG w związku ze stabilizacją frontu niemiecko-sowieckiego. Druga faza ewakuacji rozpoczęła się w lipcu 1944 r. i objęła oprócz dystryktu Galicja także tereny dystryktów: lubelskiego, warszawskiego i krakowskiego. Tym razem miejsca docelowe przenosin leżały poza obszarem Generalnego Gubernatorstwa ${ }^{5}$.

\footnotetext{
${ }^{3}$ A. Wrzyszcz, Okupacyjne sadownictwo..., s. 304-305.

${ }^{4}$ Tamże, s. 83-129.

${ }^{5}$ A. Wrzyszcz, Z badań nad ewakuacja..., s. 266-270.
} 


\section{Organizacja Placówki Zapasowej Organów Resortu Sprawiedliwości GG w Görlitz}

W trakcie tych wydarzeń powstała Placówka Zapasowa Organów Resortu Sprawiedliwości GG w Görlitz (dokładny adres to: Hindenburgplatz 18 - budynek miejscowego sądu krajowego) ${ }^{6}$. Nie udało mi się ustalić dokładnej daty jej uruchomienia, ale najbardziej prawdopodobne wydają się pierwsze dni sierpnia $1944 \mathrm{r}$. Od początku podporządkowana była kierownikowi Głównego Wydziału Sprawiedliwości w Rządzie Generalnego Gubernatorstwa (do stycznia 1945 r. - w Krakowie, a po ewakuacji w budynku Sądu Krajowego w Bayreuth) ${ }^{7}$. Podkreślić należy, że istotną rolę odgrywał też Sztab Służbowy Głównego Wydziału Sprawiedliwości GG, którego siedziba znajdowała się pod koniec sierpnia $1944 \mathrm{r}$. w Karpaczu Górnym (Brückenberg), a od października 1944 r. do stycznia 1945 r. w Jeleniej Górze (Hirschberg) ${ }^{8}$.

Kierownikiem placówki w Görlitz został Karl Kiel, dotychczasowy prezes Wyższego Sądu Niemieckiego w Lublinie i jednocześnie kierownik Wydziału Sprawiedliwości Dystryktu Lubelskiego. Organizacja wewnętrzna tej jednostki organizacyjnej została uregulowana $\mathrm{w}$ dniu 6 września 1944 r. Podzielono ją na trzy sekcje: a) wydział administracyjny, który zajmował się sprawami prowadzonymi dotąd przez dystryktowe wydziały sprawiedliwości oraz kompetencjami administracyjnymi prezesów wyższych sądów niemieckich; b) wspólny sąd; c) wspólna prokuratura. Wydział administracyjny i wspólny sąd podlegały bezpośrednio Kielowi, natomiast wspólną prokuraturę podporządkowano prokuratorowi doktorowi Neebowi 9 .

Prokurator Neeb w dniu 4 września 1944 r. miał zwierzchność nad trzema urzędnikami sądowymi i siedmioma pracownikami (w tym trzema oddelegowanymi, trzema nowo zatrudnionymi oraz jedną osobą przesiedloną do Görlitz z Rzeszowa). Specjalny był status inspektora wymiaru sprawiedliwości Pache, który miał dokonać inwentaryzacji skrzyń z mieniem resortu sprawiedliwości GG, wykonywać zadania specjalne

${ }^{6}$ AIPN, Ausweichstelle der Justizbehörden des Generalgouvernements, Görlitz - Ewakuowane Agendy Resortu Sprawiedliwości Generalnego Gubernatorstwa [dalej: EARSGG], sygn. 8, k. 5 .

${ }^{7}$ Bundesarchiv Berlin, R 52 II, Kanzlei des Generalgouverneurs, sygn. 172, k. 25.

${ }^{8}$ Sztab Służbowy Głównego Wydziału Sprawiedliwości oznaczony był symbolem JU 520-35. AIPN, EARSGG, sygn. 7, k. 2, sygn. 41, k. 1; AIPN, Regierung des Generalgouvernements - Rząd Generalnego Gubernatorstwa [dalej: RGG], sygn. V/32, k. 9.

${ }_{9}^{9}$ Pismo GWS do Placówki Zapasowej w Görlitz z 6 IX 1944 r., AIPN, RGG, sygn. V/342, k. 1 . 
zlecane przez Główny Wydział Sprawiedliwości GG, a po zakończeniu tej misji miał wrócić do swej macierzystej placówki we Wrocławiu. Prokurator Neeb w dniu 4 września 1944 r. nie był w stanie przewidzieć, czy ta obsada okaże się w przyszłości wystarczająca (przede wszystkim ze względu na płace pracowników) ${ }^{10}$.

Szczegółowy przydział czynności wewnątrz placówki wprowadził Kiel zarządzeniem z 22 września 1944 r. Na mocy tego aktu jego zastępcą został Harald von Hinüber, dotychczasowy kierownik Wydziału Sprawiedliwości Dystryktu Warszawskiego. Wydział administracyjny podzielono na cztery jednostki wewnętrzne: 1 . Galicja - dyrektor sądu krajowego Starcke, 2. Kraków - sędzia wyższego sądu niemieckiego Frenken (mogli się nawzajem zastępować), 3. Lublin - Karl Kiel, 4. Warszawa - Harald von Hinüber (mogli się nawzajem zastępować). Obsługę finansową tych jednostek zapewniało czterech urzędników (dwóch urzędników wyższego szczebla: Regen i Winkler oraz nadinspektor wymiaru sprawiedliwości Keil, a także inspektor wymiaru sprawiedliwości Bucher). Urzędnicy ci mogli się nawzajem zastępować ${ }^{11}$.

Wspólny sąd miał działać pod przewodnictwem Kiela (zastępcą był Harald von Hinüber). Wyodrębniono Wyższy Sąd Niemiecki w Görlitz (Kiel - przewodniczący, von Hinüber - zastępca przewodniczącego, Frenken - sędzia wyższego sądu niemieckiego jako członek), Sąd Niemiecki (bez sądu specjalnego) Lwów, Stanisławów i Tarnopol - dyrektor sądu krajowego Starcke, Sąd Niemiecki (bez sądu specjalnego) Chełm, Lublin i Warszawa - radca izby sądowej Tschischgale, Sąd Niemiecki (bez sądu specjalnego) Kraków i Rzeszów - Frenken. W sposób szczególny potraktowano sprawy rodzinne i spadkowe: pominięto kryterium geograficzne i wszystkie te postępowania przekazano do Sądu Niemieckiego (bez sądu specjalnego) - Lwów, Stanisławów, Tarnopol, Chełm, Lublin i Warszawa, Kraków i Rzeszów. Orzekać miał sędzia Frenken. Obsada jedynego w Görlitz Sądu Specjalnego przy Sądzie Niemieckim to: Starcke jako przewodniczący, Tschischgale jako zastępca przewodniczącego i dobierany $\mathrm{w}$ razie potrzeby członek składu orzekającego. Kwestie finansowe w sprawach karnych powierzono nadinspektorowi wymiaru sprawiedliwości Barthelowi, a w pozostałych inspektorowi wymiaru sprawiedliwości Bucherowi. Biuro obsługujące wspólny sąd stanowili: starszy sekre-

${ }^{10}$ Pismo prokuratora Neeba do Wydziału Sprawiedliwości w Dystrykcie Krakowskim z 4 IX 1944 r., AIPN, RGG, sygn. V/85, k. 31. Urzędnicy podporządkowani Neebowi to: Mett (Prokuratura Lwów), Seufert (Prokuratura Lwów), Sparn (GWS Kraków), pracownicy to: Gaubatz, Hartmann, Mauthe, Maria Sarapata - Volksdeutsch z Rzeszowa.

${ }^{11}$ Plan przydziału czynności Placówki Zapasowej w Görlitz z 22 IX 1944 r., AIPN, RGG, sygn. V/342, k. 3 . 
tarz wymiaru sprawiedliwości Langer i urzędnik Piela. Poza tym pisanie na maszynie i stenografowanie miały wykonywać cztery osoby ${ }^{12}$.

Wspólna prokuratura według przydziału czynności zarządzonego przez Kiela podlegała jak wyżej wspomniano prokuratorowi Neebowi. Zastępcą został delegowany prokurator Knoll. Podział kompetencji między nimi przedstawiał się następująco: Neeb - ogólne kierownictwo prokuraturą i całokształt spraw z dystryktu krakowskiego (bez prokuratury niemieckiej w Rzeszowie), Knoll - całokształt spraw z dystryktu warszawskiego oraz spuścizna emigracyjna prokuratury niemieckiej w Rzeszowie. Poza tym sprawy z dystryktu Galicja miał przejąć asesor sądowy Maaß. Przewidywano zatrudnienie we wspólnej prokuraturze jeszcze jednego urzędnika ewakuowanego z dystryktu lubelskiego. W strukturze Placówki Zapasowej Organów Resortu Sprawiedliwości GG w Görlitz wyodrębniono poza tym kasę (dwuosobowa obsada). Ponadto do placówki miał być oddelegowany z Sądu Lokalnego w Görlitz jeden wachmistrz sądowy ${ }^{13}$.

W kwestii obsady kadrowej szef wspólnej prokuratury w Görlitz zmienił zdanie już w pierwszej dekadzie listopada 1944 r. W piśmie do GWS GG z 10 listopada 1944 r. zwrócił się o dodatkowe zatrudnienie czterech osób (jednego prokuratora, jednego urzędnika i dwóch pracowników). Uzasadniał to koniecznością inwentaryzacji ewakuowanych akt prokuratorskich (liczonych w tysiącach poszytów) oraz potrzebą reagowania na bieżące podania i wnioski, które wpływały do podległej mu sekcji w Placówce Zapasowej Organów Resortu Sprawiedliwości GG w Görlitz. Warunki lokalowe wspólnej prokuratury były początkowo trudne, ale po kilku tygodniach wyraźnie się poprawiły i Neeb uznał je za zadowalające ${ }^{14}$.

Przydział czynności z 22 września 1944 r. był potem kilkakrotnie modyfikowany: 27 października 1944 r., 9 listopada 1944 r. i 3 stycznia 1945 r. Dwa pierwsze aneksy dotyczyły zmian przydziału czynności urzędników i pracowników wymiaru sprawiedliwości, nie miały odniesienia do sędziów i prokuratorów. Aneks z 3 stycznia 1945 r. omówiony zostanie niżej ${ }^{15}$.

Dysponujemy informacjami na temat struktury i obsady personalnej Placówki Zapasowej Organów Resortu Sprawiedliwości GG w Görlitz w dniu 25 listopada 1944 r. Organy podporządkowane tej jednostce to: wydziały sprawiedliwości dwóch dystryktów (galicyjskiego i lubelskiego) oraz częściowo wydziałów sprawiedliwości dystryktów krakowskiego i warszawskiego; wyższe sądy niemieckie (w Lublinie, Krakowie, Warsza-

\footnotetext{
${ }^{12} \mathrm{Gaß}$, Diesing, Jakober, Duffner. Tamże, k. 3-4.

${ }^{13}$ AIPN, RGG, sygn. V/342, k. 4.

${ }^{14}$ Tamże, k. 16-17.

${ }^{15}$ Tamże, k. 13, 15, k. 24; AIPN, EARSGG, sygn. 2, k. 1.
} 
wie); sądy niemieckie i sądy specjalne przy sądach niemieckich (w Chełmie, Krakowie, Lwowie, Lublinie, Rzeszowie, Stanisławowie, Tarnopolu i Warszawie); prokuratura niemiecka (w Chełmie, Krakowie, Lwowie, Lublinie, Rzeszowie, Stanisławowie, Tarnopolu i Warszawie); wszystkie niemieckie zakłady karne podległe resortowi sprawiedliwości Generalnego Gubernatorstwa z terenów zajętych przez Armię Czerwona, wszystkie organy sądownictwa nieniemieckiego z tych samych obszarów. Wykaz osób zatrudnionych w Görlitz 25 listopada 1944 r. obejmował 19 mężczyzn i 9 kobiet $^{16}$.

Na mocy aneksu z 3 stycznia 1945 r. do placówki w Görlitz został przeniesiony na stanowisko sędziego dyrektor sądu lokalnego dr Bieber. Od tego momentu Kiel wprowadził następującą obsadę sądów niemieckich: Sąd Niemiecki (bez sądu specjalnego) Lwów, Stanisławów i Tarnopol - Starcke, Sąd Niemiecki (bez sądu specjalnego) Chełm i Lublin - dyrektor sądu lokalnego dr Bieber, Sąd Niemiecki (bez sądu specjalnego) Warszawa - Tschischgale, Sąd Niemiecki (bez sądu specjalnego) Kraków i Rzeszów - Frenken. W zarządzeniu podkreślono, że powyższe sądy nie są właściwe w sprawach rodzinnych i spadkowych. Dla tych postępowań właściwy był Sąd Niemiecki (bez sądu specjalnego) Chełm, Kraków, Lublin, Lwów, Rzeszów, Stanisławów, Tarnopol, Warszawa. Na czele tego wspólnego sądu stał wyższy sędzia Frenken. Natomiast obsada Sądu Specjalnego przy Sądzie Niemieckim w Placówce Zapasowej Organów Resortu Sprawiedliwości w GG w Görlitz wyglądała następująco: dyrektor sądu krajowego Starcke jako przewodniczący, radca izby sądowej Tschischgale jako zastępca przewodniczącego, dyrektor sądu lokalnego dr Bieber jako sędzia członek składu orzekającego ${ }^{17}$.

W Placówce Zapasowej Organów Resortu Sprawiedliwości w GG w Görlitz zatrudnieni zostali urzędnicy niemieccy ewakuowani z różnych dystryktów GG. Dość silnie „reprezentowany” był dystrykt lubelski. Obok wspomnianego już Kiela w Görlitz znaleźli się: sędziowie - dr Schlitt, dr Wolf, dr Dietman, Mennicken, Zander, prokurator dr Weber, ośmiu urzędników i pracowników resortu sprawiedliwości oraz siedmiu

${ }^{16}$ Byli to: prezes sądu wyższego Kiel, wyższy prokurator Neeb, wyższy krajowy radca sądowy dr v. Hinüber, dyrektor sądu krajowego Starcke, radca izby sądowej dr Tschischgale, wyższy sędzia Frenken, radca sądu lokalnego Maaß, prokurator Knoll, urzędnik resortu sprawiedliwości Winkler, urzędnik resortu sprawiedliwości Regen, nadinspektor resortu sprawiedliwości Barthel, nadinspektor resortu sprawiedliwości Lüdemann, inspektor resortu sprawiedliwości Fach, inspektor resortu sprawiedliwości Bucher, wyższy sekretarz resortu sprawiedliwości Langer, pracownicy resortu sprawiedliwości: Brennenstuhl, Mett, Piela, Gruber. Kobiety w Görlitz zatrudnione były na stanowisku pracownika resortu sprawiedliwości: Gaß, Gaubatz, Sparn, Duffner, Rausch, Diesing, Jakober, Mauthe, Hartmann. AIPN, EARSGG, sygn. 8, k. 5.

${ }^{17}$ AIPN, RGG, sygn. V/342, k. k. 24. 
funkcjonariuszy więziennych ${ }^{18}$. We wrześniu i październiku 1944 r. aktywnym pracownikiem placówki był Harald von Hinüber, dotychczasowy kierownik Wydziału Sprawiedliwości Dystryktu Warszawskiego. Podjął on zabiegi o częściowe reaktywowanie sądownictwa niemieckiego i prokuratury niemieckiej na części dystryktu warszawskiego, który w dalszym ciągu znajdował się pod okupacją III Rzeszy. Starania te okazały się skuteczne i już w listopadzie 1944 r. Harald von Hinüber organizował w Łowiczu wiodącą dla okupowanej przez Niemców części dystryktu warszawskiego placówkę sądownictwa niemieckiego i niemieckiej prokuratury ${ }^{19}$. Planowano przeniesienie służbowe do Placówki Zapasowej Organów Resortu Sprawiedliwości GG w Görlitz prokuratora Kochmanna z dystryktu krakowskiego ${ }^{20}$. Ogółem obsada personalna placówki na początku stycznia 1945 r. obejmowała 31 osób (21 mężczyzn i 10 kobiet $)^{21}$.

\section{Działalność Placówki Zapasowej}

Już w sierpniu 1944 roku Placówka Zapasowa Organów Resortu Sprawiedliwości w GG w Görlitz przygotowała projekt instrukcji odno-

${ }^{18}$ Wykaz urzędników i pracowników ewakuowanych do Görlitz z 19 X 1944 r., AIPN, EARSGG, sygn. 7, k. 35. Urzędnicy i pracownicy resortu sprawiedliwości GG to: Winkler (Justizamtmann), Menzel (Justizoberinspektor - jego stanowisko wpisane było odręcznie i mało czytelnie), Lüdemann (Justizoberinspektor), Schön (Justizoberinspektor), Kretschmar (Justizoberinspektor), Urban (Justizobersekretär), Mihlis (jego nazwisko wpisano odręcznie, mało czytelnie - Justizobersekretär), Surmund (Justizoberwachmeister). Wśród funkcjonariuszy więziennych był jeden nadinspektor (Verwaltungsoberinspektor) - Fassel i sześciu nadwachmistrzów (Hauptwachmeister) - Wittich, Fischer, Wolf, Heckler, Schneck, Horejsi.

${ }^{19}$ Pismo kierownika Wydziału Sprawiedliwości Dystryktu Warszawskiego Haralda von Hinübera z Placówki Zapasowej w Görlitz do Głównego Wydziału Sprawiedliwości w Krakowie z 5 X 1944 r., AIPN, RGG, sygn. V/84, k. 144. Warto zauważyć, że Hinüber poruszył też kwestie personalne i stanowczo oponował przed ewentualnym zatrudnieniem na stanowisku prokuratora - Naumanna. Pismo kierownika Wydziału Sprawiedliwości Dystryktu Warszawskiego do kierownika Placówki Zapasowej w Görlitz z 4 I 1945 r., AIPN, RGG, sygn. V/82, k. 6; Pisma Hinübera do GWS z 6 XI i 18 XI 1944 r., AIPN, RGG, sygn. V/84, k. 162, 155; Pismo kierownika GWS Willego do szefa Urzędu Gubernatora Warszawskiego Gollerta z 14 XI 1944 r., tamże, k. 153.

${ }^{20}$ Pismo kierownika Wydziału Sprawiedliwości Dystryktu Krakowskiego do szefa GWS z 8 XII 1944 r., AIPN, RGG, sygn. V/81, k. 38; Pismo prokuratora Neeba do GWS w Krakowie z 10 XI 1944 r., AIPN, RGG, sygn. V/342, k. 16.

${ }^{21}$ Pismo Placówki Zapasowej z Görlitz do Sztabu Służbowego GWS w Jeleniej Górze z 5 I 1945 r., AIPN, RGG, sygn. V/82, k. 12. 
szącej się do spraw personalnych. Chodziło o sprawozdania dotyczące ewakuowanych urzędników i pracowników niemieckich, którzy stali się niepotrzebni organom resortu sprawiedliwości funkcjonującym ciągle na terenie okrojonego przez działania Armii Czerwonej Generalnego Gubernatorstwa. O treści tego projektu poinformowano właściwe organy w GG (m.in. kierownika Wydziału Sprawiedliwości Dystryktu Radomskiego, prezesa Wyższego Sądu Niemieckiego w Radomiu, kierownika Wydziału Sprawiedliwości Dystryktu Radomskiego). Sprecyzowano, że ewakuowani pracownicy pozostają $\mathrm{w}$ dalszym ciągu pod nadzorem właściwych dla nich urzędów nadzoru wojskowego Generalnego Gubernatorstwa ${ }^{22}$.

Istotną inicjatywą Placówki Zapasowej Organów Resortu Sprawiedliwości GG w Görlitz była próba kontynuacji funkcjonowania sądownictwa niemieckiego Generalnego Gubernatorstwa w okresie stabilizacji frontu wschodniego w II połowie 1944 roku. Priorytetowe znaczenie miały postępowania z zakresu prawa rodzinnego. Wiele osób podlegających jurysdykcji sądownictwa niemieckiego w GG (Reichsdeutsche, Volksdeutsche, Deutschstämmige) zostało ewakuowanych w głąb Rzeszy. Przewidziano następujący porządek realizacji tego zadania: faza pierwsza - to zebranie wszystkich dokumentów dotyczących tej problematyki, faza druga to odtwarzanie brakujących akt, w fazie trzeciej zaczęto tworzyć zasoby ewidencji dzieci, osób niepełnoletnich i ich ustawowych pełnomocników, jeśli osoby te opuściły teren Generalnego Gubernatorstwa. Realizacja fazy czwartej polegała na uruchomieniu opieki sądowej dla dzieci i osób niepełnoletnich przez Placówkę Zapasową Organów Resortu Sprawiedliwości GG w Görlitz, a fazy piątej na przekazywaniu poszczególnych spraw sądom opiekuńczym III Rzeszy ${ }^{23}$.

Już we wrześniu roku 1944 kierownik Placówki Zapasowej Organów Resortu Sprawiedliwości GG w Görlitz Karl Kiel podjął działania zmierzające do przejęcia akt i mienia służbowego organów resortu sprawiedliwości Generalnego Gubernatorstwa z dystryktu lubelskiego. Zamierzano zabezpieczyć te przedmioty i dokumenty, uporządkować je i przewieźć do Görlitz. W rezultacie ewakuacji z lata 1944 roku akta te i inna spuścizna znalazły się w Opolu (Oppeln) w gmachu miejscowej szkoły Adolfa Reitera na ul. Flurstraße 7. Misją tą został obarczony woźny sądowy Winkler, któremu polecono ścisłą współpracę z lokalnym zakła-

${ }^{22}$ AIPN, EARSGG, sygn. 7, k. 2.

${ }^{23}$ Sprawozdanie ze stanu realizacji spraw z zakresu prawa rodzinnego w Placówce Zapasowej Organów Wymiaru Sprawiedliwości w Görlitz z 31 XII 1944 r., AIPN, EARSGG, sygn. 81, k. 1-10. 
dem karnym ${ }^{24}$. W październiku 1944 r. przeniesiono do Görlitz część akt niemieckich organów należących do resortu sprawiedliwości GG z dystryktu radomskiego. Funkcjonariusze placówki przejęli obowiązki z tym związane (wydawanie odpisów oryginałów dokumentów, wystawianie zaświadczeń $)^{25}$.

Ekstraordynaryjne zadania Placówki Zapasowej Organów Resortu Sprawiedliwości Generalnego Gubernatorstwa w Görlitz przewidywał plan wspomnianego wyżej w punkcie 2 Haralda von Hinübera. Reaktywowany w Görlitz „wspólny sąd” miał przejąć rolę izby sądu specjalnego dla spraw z dystryktu warszawskiego, poza tym placówka z Görlitz miała spełniać funkcję wyższego sądu niemieckiego dla tego dystryktu i orzekać tam na posiedzeniach wyjazdowych ${ }^{26}$.

Kluczowe znaczenie miały relacje Placówki Zapasowej Organów Resortu Sprawiedliwości GG w Görlitz z centralą w Krakowie funkcjonującą do stycznia 1945 r. Kierownik Głównego Wydziału Sprawiedliwości Generalnego Gubernatorstwa Kurt Wille w lecie roku 1944 stanął na stanowisku, że ewakuacja wielu organów podległego mu resortu miała charakter tymczasowy. Założenie to miało bezpośredni wpływ na status prawny niemieckich sędziów, prokuratorów, urzędników i pracowników resortu sprawiedliwości GG przeniesionych w głąb Niemiec. W ówczesnej sytuacji militarnej i politycznej najważniejsze znaczenie miała ewidencja wojskowa. W grudniu 1944 roku podtrzymano wcześniejsze stanowisko z sierpnia. Postanowiono, że mężczyźni podlegający służbie wojskowej w Wehrmachcie, należący do szeroko rozumianej kadry resortu sprawiedliwości Generalnego Gubernatorstwa, w dalszym ciągu są podporządkowani urzędom ewidencji wojskowej funkcjonującym w GG. Bardziej problematyczna była kwestia przynależności do Volkssturmu. Rozważano, czy ewakuowani funkcjonariusze resortu sprawiedliwości Generalnego Gubernatorstwa (sędziowie, prokuratorzy, urzędnicy, pracownicy) mają się zameldować władzom wojskowym w Görlitz, czy jednak należy ich traktować jako członków Volkssturmu w GG. Szef placówki w Görlitz Kiel zwrócił się z pytaniem w tej sprawie do kierownika GWS Willego ${ }^{27}$.

${ }^{24}$ Do porządkowania mienia służbowego i akt mieli być wykorzystywani więźniowie z zakładu karnego w Opolu pod nadzorem oddelegowanego z Görlitz woźnego sądowego Winklera. Pismo Kiela do kierownika Zakładu Karnego w Opolu z 1 IX 1944 r., AIPN, EARSGG, sygn. 3, k. 1.

${ }^{25}$ AIPN, RGG, sygn. V/342, k. 13.

${ }^{26}$ AIPN, RGG, sygn. V/84, k. 144.

${ }^{27}$ Pismo kierownika Placówki Zapasowej Resortu Sprawiedliwości w Görlitz do kierownika GWS w Krakowie z 23 X 1944 r., AIPN, EARSGG, sygn. 7, k. 40; RGG, sygn. V/81, k. 2. 
W realiach III Rzeszy niezwykle istotne znaczenie miała przynależność do NSDAP. Problem ten (dzisiaj wydaje się mało istotny) w okresie od sierpnia 1944 do maja 1945 r. był bardzo ważki dla osób zatrudnionych w resorcie sprawiedliwości Generalnego Gubernatorstwa. Mimo ewakuacji na tereny III Rzeszy urzędnicy i pracownicy resortu sprawiedliwości GG mieli w dalszym ciągu pozostawać w strukturach partyjnych Generalnego Gubernatorstwa. Zabroniono im wstępować do lokalnych komórek NSDAP w Görlitz. Składki partyjne miały być w dalszym ciągu opłacane w stolicy GG. Powodowało to trudności techniczne wynikające z odległości między Krakowem a Görlitz. W październiku 1944 r. planowano upoważnienie przez władze NSDAP w stolicy Generalnego Gubernatorstwa specjalnego funkcjonariusza w Görlitz, który miałby uprawnienia do ściągania składek, i przekazanie mu do dyspozycji znaczków składek partyjnych. Przewidywano regulację ogólną (ewakuacja w głąb Niemiec dotyczyła funkcjonariuszy niemieckich nie tylko z Generalnego Gubernatorstwa, ale też z innych terenów okupowanych przez III Rzeszę). Odnośne przepisy miały być wydane przez Skarbnika Rzeszy. W ramach bieżącej reakcji kierownik GWS Wille w grudniu 1944 r. zażądał jednak listy zaległości w składkach funkcjonariuszy i pracowników jego resortu ewakuowanych w głąb Niemiec. Domagał się danych obejmujących imię i nazwisko, numer legitymacji członkowskiej, termin, od którego datują się zaległości w opłacaniu partyjnych składek ${ }^{28}$.

\section{Podsumowanie}

Reasumując należy stwierdzić, że działalność Placówki Zapasowej Organów Resortu Sprawiedliwości GG w Görlitz nie odegrała jakiejś szczególnie ważnej roli. Wydaje się, że funkcjonowanie tego organu miało pewien wpływ na bieżącą sytuację prawną i socjalną ludności niemieckiej (Reichsdeutsche, Volksdeutsche, Deutschstämmige) ewakuowanej z Generalnego Gubernatorstwa w głąb III Rzeszy w okresie od sierpnia 1944 do maja 1945 r. Na pewno Placówka Zapasowa porządkowała sprawy resortu sprawiedliwości GG oraz organizowała zatrudnienie i załatwiała inne kwestie personalne niemieckich sędziów, prokuratorów, urzędników i pracowników administracji sprawiedliwości ewakuowanych do Niemiec z Generalnego Gubernatorstwa we wskazanym wyżej okresie.

${ }^{28}$ Pismo kierownika Głównego Wydziału Sprawiedliwości GG Kurta Willego do Placówki Zapasowej Resortu Sprawiedliwości w Görlitz z 1 XII 1944 r., AIPN, EARSGG, sygn. 7, k. 57; RGG, sygn. V/81, k. 2, 5. 
W trakcie dotychczasowych badań nie odnalazłem żadnych istotnych dokumentów odnoszących się do działalności Placówki Zapasowej Organów Resortu Sprawiedliwości GG w Görlitz w stosunku do ludności nieniemieckiej (Polaków, Żydów, Ukraińców, Romów i innych narodowości), która przecież także podlegała resortowi sprawiedliwości Generalnego Gubernatorstwa.

\section{Bibliografia}

\section{Źródła}

Archiwum Instytutu Pamięci Narodowej:

Ausweichstelle der Justizbehörden des Generalgouvernements, Görlitz -Ewakuowane Agendy Resortu Sprawiedliwości Generalnego Gubernatorstwa, sygn. $2,7,3,8,41,81$.

Regierung des Generalgouvernements - Rząd Generalnego Gubernatorstwa, sygn. V/32, V/81, V/82, V/84, V/85, V/342.

Bundesarchiv Berlin:

R 52 II, Kanzlei des Generalgouverneurs, sygn. 172.

\section{Opracowania}

Grünberg K., Otręba B., Hans Frank na Wawelu, Włocławek 2001.

Madajczyk C., Polityka III Rzeszy w okupowanej Polsce, t. I, Warszawa 1970.

Winstone M., Generalne Gubernatorstwo. Mroczne serce Europy Hitlera, Poznań 2015. Witkowski W., Historia administracji w Polsce 1764-1989, Warszawa 2007.

Wrzyszcz A., Okupacyjne sadownictwo niemieckie w Generalnym Gubernatorstwie 1939-1945. Organizacja i funkcjonowanie, Lublin 2008.

Wrzyszcz A., Z badań nad ewakuacja organów resortu sprawiedliwości Generalnego Gubernatorstwa w latach 1944-1945, „Studia z Dziejów Państwa i Prawa Polskiego" [Kraków] 2008, t. XI. 